\title{
Business Studies Teachers' Level of Utilization of Concept Mapping for Effective Teaching in Secondary Schools in Anambra State
}

\author{
Okolocha Chimezie Comfort PhD \\ Ifi Chibuzor Christy \\ Department of Technology and Vocational Education \\ Nnamdi Azikiwe University,Awka \\ Nigeria
}

\begin{abstract}
The study investigated business studies teachers' level of utilization of concept mapping for effective teaching in secondary schools in Anambra State. Three research questions were answered and three null hypotheses were tested at 0.05 level of significance. Descriptive survey research design was adopted for the study and a population of 291 business studies teachers in all the public secondary schools in Anambra State were used for the study without sampling. The instrument for data collection was a structured questionnaire developed by the researchers. The instrument was structured on a five point rating scale. The instrument was validated by three experts. The reliability of the instrument was ascertained using Cronbach alpha to get a coefficient of 0.85. The arithmetic mean and standard deviation were used to analyze data in relation to the research questions while the z-test was used to test the hypotheses at 0.05 level of significance. The findings of the study revealed that business studies teachers in secondary schools in Anambra State highly utilized concept mapping in planning instruction, delivering classroom instruction and assessment. Based on the findings, the researchers recommended among others that the practice of mentoring should also be encouraged among business studies teachers so that the less experienced teachers would share in the knowledge of the experienced teachers on how to use concept mapping in delivering classroom instruction and assessment as well as other skills they have acquired over the years.
\end{abstract}

Keywords: Concept mapping, Effective teaching, Planning instruction, assessment

\subsection{Introduction}

Education is the bedrock for the growth and development of any nation. This is the reason for the continuous effort and changes put in place to get a good educational system that will give the pupils and students qualitative and pragmatic education in order to foster development in the country. In Nigeria, the educational system has experienced changes since its independence, from 6-5-4 to 6-3-3-4 to 9-3-4. The current 9-3-4 system of education adopted in 2008 comprises of nine years basic education, three years senior secondary education and four years tertiary education. The nine years basic education is made up of six years primary education and three years upper basic education otherwise referred to as junior secondary education. The junior secondary education is the education that comes immediately after the primary education. The Federal Republic of Nigeria (FRN) (2014) stated that the junior secondary education shall be both pre-vocational and academic and shall teach basic subjects that will enable pupils acquire further knowledge and skills for entrepreneurship and educational advancement among other goals set out to achieve. Every student is the junior secondary school is expected to undertake at least one subject from the pre-vocational electives.

Business studies are one of the elective pre-vocational subjects. It is packed with all the relevant knowledge, skills, experiences and activities that will lead to the realization of the goals of junior secondary education. Business studies according to Okoro (2013) are a subject that promotes saleable skills acquisition and employment generation. It is made up of five major components namely: Office Practice, Commerce, Book Keeping, Shorthand and Typewriting (Igbaji, 2013). Business studies involves a lot of activities ranging from those requiring students to discuss issues, solve problems using application software, participate in business simulation, think critically, work cooperatively and make business decisions. 
Mkandawire (2010) opined that teachers are the most important human resources in curriculum implementation. This implies that sufficient supply of qualified business studies teachers is a pre-requisite for attaining the goals of business studies (Okorie \& Okoli, 2014).

Business studies teachers are those charged with the responsibility of educating the students on the subject of business studies. The National Business Education Association (2004) defined business studies teachers as those teachers that teach business studies as a subject in the junior secondary schools. They are expected to have at least a Nigeria Certificate in Education (NCE) certificate in business related programme. Burwan and Mutendwahotte (2012) opined that teachers need to employ teaching strategies and techniques that will guarantee effective learning. According to Anyaduba cited in Ogbaekirigwe (2010) business studies teachers in addition to other qualities must have adequate knowledge of the subject, good teaching skills and competence in a variety of teaching techniques in order to be effective in teaching?

Teaching has been defined by Morrison cited in Yunus (2013) as an intimate contact between a more mature personality (teacher) and a less mature one (student) which is designed to further the education of the latter. Teaching involves a cluster of activities like explaining, deducting, questioning, motivating, keeping record of students' progress among many others. Teaching is a process of engaging students in activities that will enable them to acquire the knowledge, skills as well as worthwhile values and attitude.

According to Galindo (2013), effective teaching is the process whereby a teacher creates the conditions and experiences that will help learners acquire knowledge, apply it and retain it. The primary purpose of teaching is to facilitate students' learning. Effective teaching process therefore covers what happens from the planning of the instruction, the actual delivery of the planned instruction as well as assessing the students.

A well planned instruction will facilitate effective instructional delivery which will be evidenced in good academic performance by the learner when assessed. The ability to successfully deliver instruction is a big indicator of a teacher's effectiveness. Effective delivery of classroom instruction requires an understanding of the subject or concept, the ability to differentiate learning opportunities, incorporate pedagogical practices and check for understanding. The teaching process cannot be said to be effective if there is no means of assessing the students. An effective teacher therefore must employ a variety of methods and techniques in teaching, so as to make the process learner-centered and create a conducive atmosphere for the learner to be an active participant while the teacher becomes the facilitator. Therefore, it is very important that teachers are equipped with the necessary knowledge and skills on various instructional methods and techniques so as to be effective. Alhomaidan (2015) identified concept mapping as a teaching technique that brings about effective teaching.

Concept mapping is the technique for visualizing the relationships among different concepts. It is the process of constructing concept maps. According to Kinchin (2014) this technique has been proven to be effective in teaching. Concept maps are graphical tools for organizing and representing knowledge. They include concepts, usually enclosed in circles of boxes and the relationship between concepts indicated by connecting lines linking two concepts (Novak \& Canas, 2008). It is a hierarchical form of structure diagram that illustrates conceptual knowledge and their relationship with specific topic from general to specific concepts. Two important features of a concept map is the hierarchical structure represented in a good map and the presence of cross-links. The most general and most inclusive concepts are placed at the top of the map and the more specific and less general concepts arranged hierarchically below. Words on the linking line are used to show the relationship between concepts.

Concepts can be defined as perceived regularity or pattern in events or objects, or records of events or objects, designated by a label. The label for most concepts could be a word, or symbols such as + or $\%$ and sometimes more than one word. When two or more concepts are connected using linking words or phrases to form meaningful statements they are referred to as propositions. Propositions are statements about some object or event in the universe, either naturally occurring or constructed (Canas \& Novak, 2009). It advocates the use of both verbal and non-verbal processing and representation of information. The dual coding theory of Paivio (1986) estapulates that there two ways in which human beings processes information; the verbal and the non-verbal (imagery). For effective teaching to be attained, the instructional technique to be used should combine verbal and images as seen in concept mapping. There are several uses of concept mapping in education which include: planning classroom instruction, delivering classroom instruction, knowledge organization, assessment and many others. Concept mapping is useful in planning classroom instruction. 
Planning classroom instruction with concept maps, makes it learner- centered and gives the teacher a comprehensive understanding of what he is preparing to teach, thereby eliminating sequencing errors and enabling the teacher to develop lessons that are truly interdisciplinary. It enables the teacher plan and design units of study that are meaningful, relevant, pedagogically sound, well integrated and interesting to students.

Concept mapping is also used in the course of instruction as an integral, on-going feature of the teaching-learning process to consolidate educational experiences. Ekima (2013) identified concept mapping as a veritable tool that fosters meaningful learning. Visual representation of knowledge helps to create lasting impact and retention on the minds of the learners. Since learning is structured by the learner and not necessarily what the teacher says in the classroom, the use of concept mapping in classroom instruction aids the learner to integrate new knowledge into what he knows previously. Concept mapping promotes brainstorming and critical thinking. It makes learners active participants either as individuals or groups thereby facilitating cooperative learning. Studies have shown that concept mapping is very effective when used for classroom instruction (Novak \& Canas, 2008).

Langan (2015) opined that another important use of concept mapping in education is assessment. Concept mapping helps to identify both valid and invalid ideas held by students. It can be used in assessing knowledge possessed by students before starting a program, course or subject and their developing knowledge of course materials. Concept mapping as an evaluation tool can assess the students' cognitive, affective and psychomotor domain. Alhomaidan (2015) in his study on the effectiveness of concept mapping as an instructional strategy found out that concept mapping had positive impact on students' learning as those taught with concept mapping performed better than their counterpart taught without concept mapping in the post-test. Also, Udeani and Okafor (2012) investigated the effect of concept mapping instructional strategy on the biology achievement of senior secondary slow learners. It was found out that concept mapping is potent in bringing about meaningful learning among slow learners as the experimental group taught with concept mapping performed significantly better than those taught without it. Business studies teachers should therefore adopt this invaluable technique in teaching for more effectiveness and better performance.

\subsection{Statement of the Problem}

Concept mapping has been discovered to be most effective in the teaching and learning process (Novak \& Canas, 2009). This is as a result of its numerous benefits which include facilitating meaningful learning, planning instruction, encouraging cooperative learning, consolidating educational experiences, supplementing traditional writing of assignments, communicating complex ideas, increasing retention and many more (Ausubel, 2000; Canas, 2003; Canas \& Novak, 2009). Even though not stipulated as one of the teaching methods in business studies curriculum, the curriculum planners encourage teachers to use a variety of teaching techniques in other to realize the objectives of the subject.

The objectives of business studies include equipping students with the orientation and basic skills they require in order to start their own businesses for those who may not have the opportunity for further training. However, observation and research has shown that students do not have a comprehensive understanding of concepts taught in business studies as these students are unable to apply the knowledge and skills supposedly acquired from the subject to real life situations. A good number of students upon completing the compulsory basic education still lack the drive and competence required to set up and manage well their own businesses though they may not have opportunity for further training. This could mean that the type of instructional methods and techniques used in teaching them might not be adequate. According to Okebukola cited in Molokwu (2015) poor instructional methods leads to poor learning outcome. Galindo (2013) opined that meaningful learning brings about changes in the long-term memory. It may be that teachers did not use concept mapping in teaching, therefore the students did not have adequate understanding of concepts presented in the classroom thereby could not apply them in real life situation. Therefore, the researcher sought to find out business studies teachers' level of utilization of concept mapping for effective teaching in secondary schools in Anambra State.

\subsection{Purpose of the Study}

The main purpose of the study was to determine business studies teachers' level of utilization of concept mapping for effective teaching in secondary schools in Anambra State. Specifically, the study determined business studies teachers' level of utilization of:

1. Concept mapping in planning instruction in secondary schools in Anambra State.

2.Concept mapping in delivering classroom instruction in secondary schools in Anambra State. 
3. Concept mapping in students' assessment in secondary schools in Anambra State.

\subsection{Research Questions}

The following research questions were raised to guide the study:

1. To what level do business studies teachers utilize concept mapping in planning instruction in secondary schools in Anambra State?

2. To what level do business studies teachers utilize concept mapping in delivering classroom instruction in secondary schools in Anambra State?

3. To what level do business studies teachers utilize concept mapping for assessment in secondary schools in Anambra State?

\subsection{Hypotheses}

The following null hypotheses were tested at 0.05 level of significance. Business studies teachers do not differ significantly in their mean ratings on the level of utilization of concept mapping for planning instruction based on years of teaching experience.

1. Business studies teachers do not differ significantly in their mean ratings on the level of utilization of concept mapping for delivering classroom instruction based on years of teaching experience.

2. Business studies teachers do not differ significantly in their mean ratings on the level of utilization of concept mapping for assessment based on years of teaching experience.

\subsection{Method}

The design of the study was a descriptive survey. This design was chosen and considered appropriate for the study because it sought the opinion and views of business studies teachers on their level of awareness and utilization of concept mapping for effective teaching. This is in line with Nworgu (2015) who recommended the descriptive survey design for studies that involve eliciting the opinions, attitudes and perception of a group of people or a part of the group that is considered to be representative of the entire group. The study was carried out in all the public secondary schools in Anambra State. Anambra State is located in the South-East, Nigeria. Anambra State is made up of six education zones namely: Aguata, Awka, Nnewi, Ogidi, Onitsha and Otuocha. The choice of the State for the study was therefore informed by the large number of public secondary schools and the presence of many employers of labour that employs the products of business studies within the State.The entire population of the study consists of 291 business studies teachers in the entire 257 public secondary schools in Anambra State. The entire population was used for the study because the size was considered manageable. Hence, there was no sampling for the study.

The instrument for data collection was a structured questionnaire made of up of two sections- A and B. Section A dealt with personal data of the respondents such as their years of experience while section B contained 28 items based on the research questions raised. The instrument was rated on a five-point rating scale but of Very Highly Utilized (VHU), Highly Utilized (HU), Moderately Utilized (MU), Lowly Utilized (LU) and Very Lowly Utilized (VLU) with values 5, 4, 3, 2 and 1 respectively. The instrument was validated by three experts and the reliability of the instrument was established using Cronbach Alpha method. was used to check the internal consistency of the instrument. The reliability coefficient was 0.85 which was considered highly reliable and internally consistent for the study.

Data were obtained using a structured questionnaire developed by the researchers for the study. Out of the 291 copies of the questionnaire distributed to the respondents, 280 copies were filled and returned by the respondents and were used for data analysis. Data analysis involved the use of both descriptive and inferential statistics. Arithmetic mean and standard deviation were used to analyze data related to the research questions and to ascertain the homogeneity or otherwise of the respondents' mean scores respectively. The mean ratings were interpreted using the real limit of numbers of the scale values of: Very Highly Utilized (4.50 - 5.00), Highly Utilized (3.50 - 4.49), Moderately Utilized (2.50 _ 3.49), Lowly Utilized (1.50 _ 2.49) and Very Lowly Utilized (0. $50-1.49)$. The z-test statistical tool was used to test the hypotheses at 0.05 level of significance. A null hypothesis was accepted where $\mathrm{z}$-calculated value was less than or equal to the $\mathrm{z}$-critical value but where $\mathrm{z}$ calculated was greater than the $\mathrm{z}$-critical value, the null hypothesis was not accepted. 


\section{Results}

Research Question 1: To what level do business studies teachers utilize concept mapping in planning instruction in secondary schools in Anambra State?

Table 1: Respondents' mean rating on the utilization of concept mapping for planning instruction $\mathbf{N}=\mathbf{2 8 0}$

\begin{tabular}{|c|c|c|c|c|}
\hline $\mathbf{S} / \mathbf{N}$ & $\begin{array}{l}\text { Utilization of concept mapping in planning } \\
\text { instruction }\end{array}$ & Mean & SD & Remarks \\
\hline 1. & To organize the day's lesson & 4.01 & 0.72 & Highly utilized \\
\hline 2. & To establish logical instructional sequence & 3.95 & 0.74 & Highly utilized \\
\hline 3. & To analyze the instructional task & 4.02 & 0.78 & Highly utilized \\
\hline 4. & To represent the result of conceptualization & 4.20 & 0.73 & Highly utilized \\
\hline 5. & For preparing teaching aid & 4.19 & 0.71 & Highly utilized \\
\hline 6. & As a guide for the instructional delivery process & 4.26 & 0.75 & Highly utilized \\
\hline 7. & $\begin{array}{l}\text { To diagrammatically represents step by step plans } \\
\text { made for the day's lesson }\end{array}$ & 3.58 & 0.72 & Highly utilized \\
\hline 8. & $\begin{array}{l}\text { To collaborate with other teachers in the same } \\
\text { discipline while planning }\end{array}$ & 3.59 & 0.73 & Highly utilized \\
\hline 9. & $\begin{array}{l}\text { To collaboration with other teachers in other } \\
\text { discipline }\end{array}$ & 3.53 & 0.74 & Highly utilized \\
\hline \multirow[t]{2}{*}{10.} & To subject lessons plans to peer review & 3.56 & 0.78 & Highly utilized \\
\hline & Cluster Mean & 3.89 & & Highly utilized \\
\hline
\end{tabular}

The result in Table 1 shows that all the items raised were highly utilized by the respondents. The cluster mean of 3.89 indicates that business studies teacher's highly utilized concept mapping for planning instruction. The standard deviations for the items are within a close range of 0.71-0.78 which shows that the respondents were homogeneous in their opinions.

\section{Research Question 2:}

To what level do business studies teachers utilize concept mapping in delivering classroom instruction in secondary schools in Anambra State?

Table 2: Respondents' mean rating on utilization of concept mapping for delivering classroom instruction $\mathbf{N}=\mathbf{2 8 0}$

\begin{tabular}{llccl}
\hline S/N & $\begin{array}{l}\text { Utilization of concept mapping for delivering } \\
\text { classroom instruction }\end{array}$ & Mean & SD & Remarks \\
\hline 11. & To set induce students & 3.53 & 0.82 & Highly utilized \\
12. & As students' activity during instruction & 3.47 & 0.84 & Moderately utilized \\
13. & To ascertain the students' preparedness level & 3.53 & 0.86 & Highly utilized \\
14. & To promote co-operative learning & 3.52 & 0.81 & Highly utilized \\
15. & To summarize the day's lesson & 3.51 & 0.83 & Highly utilized \\
16. & For closure of lessons & 3.56 & 0.81 & Highly utilized \\
17. & To connect new knowledge with previous knowledge & 3.52 & 0.79 & Highly utilized \\
18. & To carry out revision & 3.54 & 0.85 & Highly utilized \\
19. & To construct maps collaboratively with the students & 3.56 & 0.87 & Highly utilized \\
& during instruction & & & Highly utilized \\
\hline
\end{tabular}

The result in Table 2 shows that business studies teachers in Anambra State highly utilized concept mapping to set induce students, ascertain the students' preparedness level, promote cooperative learning, for closure of lessons, summarize the day's lesson, carry out revision, connect new knowledge with previous knowledge and to construct maps collaboratively with students during instruction with mean values ranging from 3.51 to 3.56 and moderately utilized as students' activity during instruction with a mean rating of 3.47 . The cluster mean of 3.53 indicates that business studies teachers' highly utilized concept mapping for delivery classroom instruction. 
The standard deviations for the items are within a close range of 0.79-0.87 which shows that the respondents were homogeneous in their opinion.

\section{Research Question 3:}

To what level do business studies teachers utilize concept mapping for assessment in secondary schools in Anambra State?

Table 3: Respondents mean rating on utilization of concept mapping for assessment $\mathbf{N}=\mathbf{2 8 0}$

\begin{tabular}{|c|c|c|c|c|}
\hline $\mathbf{S} / \mathbf{N}$ & Utilization of concept mapping for assessment & Mean & SD & Remarks \\
\hline 20. & $\begin{array}{l}\text { Make students to draw concept maps at the beginning } \\
\text { of the lesson or topic(pre-assessment) }\end{array}$ & 3.96 & 0.77 & Highly utilized \\
\hline 21. & $\begin{array}{l}\text { Determine students misconceptions about a concept or } \\
\text { topic }\end{array}$ & 3.94 & 0.73 & Highly utilized \\
\hline 22. & $\begin{array}{l}\text { Evaluate students' understanding at the end of the } \\
\text { lesson or topic }\end{array}$ & 4.00 & 0.76 & Highly utilized \\
\hline 23. & $\begin{array}{l}\text { Ask students to summarize the lesson by drawing a } \\
\text { concept map }\end{array}$ & 4.07 & 0.72 & Highly utilized \\
\hline 24. & Give students group tasks & 2.53 & 0.75 & $\begin{array}{l}\text { Moderately } \\
\text { utilized }\end{array}$ \\
\hline 25. & Set completion test items (fill-in-the-blank) & 2.59 & 0.78 & $\begin{array}{l}\text { Moderately } \\
\text { utilized }\end{array}$ \\
\hline 26. & Assess students' performance at the end of the term & 2.59 & 0.78 & $\begin{array}{l}\text { Moderately } \\
\text { utilized }\end{array}$ \\
\hline 27. & Give take home assignments & 2.54 & 0.73 & $\begin{array}{l}\text { Moderately } \\
\text { utilized }\end{array}$ \\
\hline 28. & $\begin{array}{l}\text { Encourage students to assess themselves while } \\
\text { studying }\end{array}$ & 2.62 & 0.71 & $\begin{array}{l}\text { Moderately } \\
\text { utilized }\end{array}$ \\
\hline & Cluster Mean & 3.50 & & Highly Utilize \\
\hline
\end{tabular}

The result in Table 3 shows that business studies teachers in Anambra State moderately utilized concept mapping to give students group tasks, set completion test items, give take home assignments, assess students' performance at the end of the term and encourage students to assess themselves while studying. This yielded mean values ranging from 2.53 to 2.62 but highly utilized concept mapping to evaluate students' understanding, determine student's misconceptions about a topic and ask students to draw a concept map at to summarize the lesson or at the beginning of the lesson with mean values ranging from 3.94 to of 4.07 . The cluster mean of 3.50 indicates that business studies teachers highly utilized concept mapping for assessment. The standard deviations for the items are within a close range of $0.71-0.78$ which shows that the respondents were homogeneous in their opinions.

\section{Hypothesis 1:}

Business studies teachers do not differ significantly in their mean ratings on the level of utilization of concept mapping for planning instruction based on years of teaching experience.

Table 4: z-test analysis of respondents' mean ratings on utilization of concept mapping in planning instruction based on years of experience.

\begin{tabular}{|lcccccccc|}
\hline $\begin{array}{l}\text { Years of } \\
\text { Experience }\end{array}$ & N & Mean & SD & $\boldsymbol{\alpha}$ & df & z-cal & z-crit & Remark \\
\hline $0-5$ & 89 & 4.30 & 0.91 & & & & & \\
Above 5 & 191 & 4.05 & 0.94 & & & & & \\
\hline
\end{tabular}

The result in Table 4 haws that the calculated $\mathrm{z}$ - value of 0.68 is less than the critical $\mathrm{z}$-value of 1.96 at 0.05 level of significance and 278 degree of freedom. This means that business studies teachers did not differ significantly in their mean ratings on the level of utilization of concept mapping for planning instruction on the basis of years of experience. Therefore, the hypothesis is accepted. 


\section{Hypothesis 2:}

Business studies teachers do not differ significantly in their mean ratings on the level of utilization of concept mapping for delivering classroom instruction based on years of teaching experience.

Table 5: z-test analysis of respondents' mean ratings on utilization of concept mapping in delivering classroom instruction based on years of experience

\begin{tabular}{lrrrrrrrrr}
\hline $\begin{array}{l}\text { Years of } \\
\text { Experience }\end{array}$ & $\mathbf{N}$ & Mean & SD & $\boldsymbol{\alpha}$ & df & z-cal & z-crit & \multicolumn{2}{c}{ Remark } \\
\hline $0-5$ & 89 & 4.28 & 0.69 & & & & & & \\
& & & & & 0.05 & 278 & 3.91 & 1.96 & Significant \\
Above 5 & 191 & 3.85 & 1.17 & & & & & & \\
\hline
\end{tabular}

The result in Table 5 shows that the calculated $\mathrm{z}$ - value of 3.91 is greater than the critical $\mathrm{z}$-value of 1.96 at 0.05 level of significance and 278 degree of freedom. This means that business studies teachers differ significantly in their mean ratings on the level of utilization of concept mapping in delivering classroom instruction on the basis of years of experience. Therefore, the hypothesis is rejected.

\section{Hypothesis 3:}

Business studies teachers do not differ significantly in their mean ratings on the level of utilization of concept mapping for assessment based on years of teaching experience.

Table 6: z-test analysis of respondents' mean ratings on utilization of concept mapping for assessment based on years of experience.

\begin{tabular}{lrlrllllll}
\hline $\begin{array}{l}\text { Years of } \\
\text { Experience }\end{array}$ & N & Mean & SD & $\boldsymbol{\alpha}$ & df & z-cal & z-crit & Remark \\
\hline $0-5$ & 89 & 4.12 & 0.75 & & & & & \\
Above 5 & 191 & 3.73 & 1.20 & & & & & & \\
\hline
\end{tabular}

The result in Table 6 shows that the calculated $\mathrm{z}$ - value of 3 is greater than the critical $\mathrm{z}$-value of 1.96 at 0.05 level of significance and 278 degree of freedom. This means that business studies teachers differ significantly in their mean ratings on the level of utilization of concept mapping for assessment. Therefore, the hypothesis is rejected.

\subsection{Discussion of Findings}

The results of research question one indicated that business studies teachers highly utilized concept mapping in planning instuction. Taie (2014) stated that concept mapping is used by teachers for effective planning of instruction. Trentin, Gerab and Ching (2015) in support asserted that business teachers facilitates the development of deep and meaningful learning as a result of using concept mapping in planning instruction. The findings of the first hypothesis revealed that business studies teachers do not differ significantly in their mean ratings on the level of utilization of concept mapping in planning instruction based on their years of experience. This is in consonance with Nwoke and Uzoma (2015) who stated that number of years a teacher has put in does not guarantee knowledge and application of instructional strategies and techniques that leads to effectiveness. Any teacher that aims at ensuring that the students learn meaningfully will not neglect this indispensable technique called concept mapping.

The findings for research question two revealed that business studies teachers highly utilized concept mapping in delivering classroom instruction. Salmon and Kelly (2012) asserted that teachers use concept mapping in teaching as they believe that students understand better and retain for longer period when concepts and their relationship are visualized. Concept maps could be prepared by the teacher before coming to class and used to capture the attention of the students and as an instrucional material. 
Abdulmunim, Hammani and Usman (2012) stated that selecting appropriate and best instructional material for teaching business studies brings about the best learning outcome. Visually representing the concept to be taught, helps to consolidate learning experiences while knocking out the misconceptions and misunderstandings posed by complex concepts. The test of hypothesis two showed significant difference in the mean ratings of business studies teachers utilization of concept mapping for delivering classroom instruction based on years of experience. This is in agreement with the saying that practice leads to perfection. Alshammari (2015) in agreement stated that different methods of using concept maps in teaching and learning is rapidly developing over the years. Therefore, teachers who use concept maps in delivering instruction will discover more ways of using it.

The result of research question three revealed that business studies teachers highly utilized concept mapping for assessment. Vodovzor and Raud (2014) agreed to this by stating that teachers use concept map to measure the level of understaning that the students have acquired. Adequate understanding of the present subject matter is very important as this facilitates or inhibits future learning. Vodovzor and Raud (2014) said that teachers use concept mapping to measure mental skills of students. Asking students to draw concept maps enables them understand the subject matter well and reveals their superficial or disjointed understanding thereby providing a kind of feedback to them. The test of the fourth hypothesis showed that business studies teachers significantly differ in their mean ratings on their level of utilization of concept mapping for assessment based on years of experience. Udosion (2007) agreed that years of experience do not affect the type of tool a teacher uses in assessing the students.

\subsection{Conclusion}

It was concluded that business studies teachers in secondary schools in Anambra State highly utilized concept mapping in planning instruction, delivering classroom instruction and assessment. However they should improve in its use as students' activity as this practise will boost the understanding and knowledge of students.

\subsection{Recommendations}

Based on the findings and conclusion of the study, the following recommendations are made :

1. The practice of mentoring should be encouraged among business studies teachers so that the less experienced teachers would share in the knowledge of the experienced teachers on how to use concept mapping in delivering classroom instruction and assessment as well as other skills they have acquired over the years.

2. Stakeholders in junior secondary education such as Anambra State Universal Basic Education Board (ASUBEB), Post Primary School Service Commission (PPSSC), National Union of Teachers (NUT), state government and others should join efforts and organize regularly workshops, symposia and seminars to retrain business studies teachers on emerging ways concept maps could be used in teaching. Educational assosciations like Association of Business Educators in Nigeria (ABEN) should also create awareness of its importaance during their annual conferences..

3. Prospective teachers while undergoing training should be equipped with adequate knowledge and skill on the use of concept mapping as a teaching technique and the various ways and stages in which it can be used in teaching.

\section{References}

Abdulmuminim, U., Hammani, B. \& Usman, A. (2012). Teacher competencies in the use of instructional materials for teaching agricultural education, its impact on students' academic performance. Africa Journal of Research and Administration, 5(2), 112-116.

Alhomaidan, A.M.A. (2015). The effectiveness of concept mapping on learning: A study in Saudi college-level context. American Journal of Educational Research, 3(8),1010-1014.doi:10.12691

Alshammari, M.K. (2015).The effect of conceptual maps strategy in teaching foundation curriculum on the achievement of students of Afif Education College in Saudi Arabia. British Journal of Education, 3 (4), $37-47$.

Ekima, S.T. (2013). Effect of concept mapping instructional strategy on junior secondary school studensts' knowledge of multiculturalism in the global $21^{\text {st }}$ century social studies classroom. Journal of Education and Practice, 13(4), 15-21. 
Federal Republic of Nigeria (2014). National Policy on Education. Lagos: National Education Research and Development Council.

Galindo, I. (2013). Five stages for effective teaching and meaningful learning in the classroom. Retrieved from www.wabashcenter.typepad.com/12

Langan, K. (2015). Concept mapping in the higher education classroom. University library

Nwoke, B.I., Iwu, A. \&Uzoma, P.O. (2015). Effect of concept mapping approach on students' achievement in mathematics in secondary schools. JORIND, 13(1), 193-199

Mkandawire, S.B. (2010). Impediments to curriculum implementation in learning Institutions. Circulatory Article for Information Resource. Retrieved from www.indescence.com

Novak, J.D. \& Canas, A.J. (2008).The theory underlying concept maps and how to construct and use them. Pensacola,Florida: Institute of Human and Machine Cognition

Ogbaekirigwe, A.C. (2010). Analysis of constraints of business studies in junior secondary schools in Ebonyi state. Journal of Business and Vocational Education, 1(1), 121-132.

Okorie, O. \& Okoli, B.E. (2014). Adequacy of business studies teachers for implementation of upper basic education business studies curriculum in Nigeria. British Journal of Education, 2(5), 13-21.

Okoro, J. (2013).Strategies for enhancing the functionality of business studies in the universal basic education programme in the south south Nigeria. Journal of Education and Practice, 2(4), 131-136

Paivio, A. (1986). Mental representation. Newyork: Oxford University

Salmon, D. \& Kelly, M. (2012). Using concept mapping to enhance teachers' metacognition. Teaching Educational Psychology, 2(3), 89-92.

Taie, E.S. (2014). Concept mapping as an innovative teaching strategy to enhance cognitive learning in nursing administration courses. International Journal of Innovative Education and Research, 2(7), 48-53.

Trentin, P.H., Gerab, F.\& Ching, H.Y.(2015).The role of concept mapping in the development of a pedagogical project of a business course. Science and Education Journal 2(5), 121-127

Udoisong, M.A. (2007). Teachers' competency and students' academic performance in religious education in secondary schools in Uyo LGA. An unpublished Master Thesis submitted to University of Uyo,Uyo.

Vodovozor,V. \& Raud, Z.(2014). Concept maps for teaching, learning and assessment in electronics. Education Research International 